\title{
Chondriosomes and the Primordia of Chloroplasts and Leucoplasts.
}

\author{
BY \\ DAVID M. MOTTIER, \\ Professor of Botany in Indiana University.
}

With Plate I.

$\mathrm{T}$ the cytoplasm of the cells of many plants, representing all the great groups of the Vegetable Kingdom, small rod-shaped or granular bodies have been described under the name chondriosomes. It has been claimed that these bodies are readily observed in living cells of certain plants, but, in general, they are to be definitely demonstrated only after the application of certain fixing fluids and stains. The fact that bodies designated by the term chondriosome are not visible after the application of some of the best and more commonly known cytological methods used in the study of nuclear phenomena accounts for their comparatively late discovery by botanists. However, the rather long list of papers that have appeared during the last decade is an indication of the lively interest taken in the study of these bodies, which are so numerous and conspicuous in certain parts of many plants.

From a perusal of the literature, one is convinced that the several investigators have applied the term chondriosome to markedly different objects in the cell. This is definitely pointed out by Cavers (1914), who, in a careful review, has summarized the literature appearing prior to the year 1914. A discussion of the literature will, therefore, be unnecessary here, and the reader is referred to the above review by Cavers, where a complete bibliography of the literature then existing will be found.

\section{METHODS.}

After some experience I have found it very desirable to make some modifications in the use of certain methods recommended by others for the study of the various bodies described under the general term chondriosome,

[Annals of Botany, Vo1. XXXII. No. CXXV. January, Igr8.] 
and, since others may decide to use the processes followed by me, it may be worth while to give a somewhat detailed statement of the methods employed.

Different killing fluids were used at first in fixing material, but the following proved to be so much more satisfactory for the tissues studied that it was finally employed exclusively:

$\begin{array}{lllll}\text { I per cent. chromic acid. } & \cdot & \cdot & \bullet & \cdot\end{array}$

In many instances the glacial acetic acid was omitted altogether, although the cell contents, especially the nucleus, seemed to be brought out more clearly and definitely with the small quantity of the acetic acid. No satisfactory results were obtained when the amount of acetic acid in the above mixture was increased to one cubic centimetre. It is seen that one of the best combinations of these three acids used in fixing cells for the study of nuclear phenomena is quite unsatisfactory for the demonstration of chondriosomes. While the fixing of nuclei with the above mixture gave good results for some tissues, yet, in others, the details were not so well brought out. This was especially noticeable with nuclei in the resting condition. Less difference was observed in mitotic stages.

In the literature one finds listed reagents which are suitable for chondriosomes, and others in which these bodies are dissolved. In some cases the statements of different writers seem to be contradictory. It is not easy to understand this unless the different authors refer to different structures under the same name; or it is probable that the killing reagent which would preserve these bodies in one plant would dissolve them in another or render them incapable of being stained. I am inclined to believe from my experience, although I have not been able to test the matter thoroughly, that in some plants the bodies that may reasonably be placed in the category of chondriosomes are not injured by the amount of acetic acid contained in the chromo-osmo-acetic mixture used in the study of nuclear phenomena.

Specimens were allowed to remain in the fixing fluid from thirty-six to forty-eight hours. After fixation the procedure varied with the method of staining to be employed. In all tissues studied by me two methods of staining were followed, the one used as a check upon the other, and in all cases the results were essentially the same. These two staining processes consisted, respectively, of a modification of Benda's crystal violet, and the well-known iron-alum-haematoxylin stain. 


\section{Staining with Crystal Violet.}

If the crystal violet is to be used, the procedure is as follows:

a. Wash in water one to two hours.

b. Equal parts pyroligneous acid (rect.) and I per cent. chromic acid, twenty-four hours.

c. Two per cent. aqueous solution of potassium bichromate, twenty-four hours.

d. Wash in water twenty-four hours.

$e$. Dehydrate very carefully and bring into paraffin.

$f$. Treat the sections on the slide with the iron mordant $\left(\left(\mathrm{NH}_{4}\right)_{2} \mathrm{Fe}_{2}\left(\mathrm{SO}_{4}\right)_{4}\right.$. ${ }_{2} 4 \mathrm{H}_{2} \mathrm{O}$ ), twenty-four hours. Instead of a 4 per cent. solution, only 3 per cent. was used.

g. Slides are now rinsed with water.

$h$. Treat with alizarin sodium sulphonate (Kahlbaum). This stain is made by adding from one to several cubic centimetres of a saturated solution in 70 per cent. alcohol to 80 to 100 c.c. of water.

$i$. Pour off with water and let dry in the air, standing slide on end.

$j$. Stain with Benda's crystal violet by warming to the point of forming vapour.

$k$. After cooling, pour off with water and let dry as above.

l. Destain with a 10 per cent. solution of acetic acid under microscopic control. This requires from a few seconds to as many minutes, depending upon the character of the tissue and the thickness of the section.

$m$. When the desired stain is reached, pour off with water and dehydrate quickly with absolute alcohol. The alcohol is immediately followed with clove oil-orange $G$, which is allowed to remain until the cell walls begin to show a slight orange colour, or until the desired counterstain is reached.

$n$. Now pour off the clove oil-orange $\mathrm{G}$ with xylol and add cedar oil, which is followed by Canada balsam and a cover-glass.

The primordia of leucoplasts and chloroplasts and the chondriosomes are stained blue. Although $I$ have used the alizarin of several times the strength of Benda's formula, this stain imparts only a pale rose colour to the nucleus, or no effect is noticeable. This stain is unnecessary. The crystal violet was prepared as follows as given by Benda :

Saturated solution of crystal violet in 70 per cent. alcohol, one part ; Io per cent. $\mathrm{HCl}$ in 70 per cent. alcohol, one part; aniline water, two parts.

\section{Staining with Iron-Alum-Haematoxylin.}

a. After fixation, as in the preceding process, the specimens are washed in water twenty-four hours (in flowing water, or in several changes). 
b. Dehydrate and bring into paraffin.

c. Sections on the slide remain in the mordant (3 per cent.) four to six hours.

$d$. Rinse with water and stain twelve hours or longer in a one-half per cent. aqueous solution of haematoxylin.

e. Destain with a 3 or 4 per cent. solution of the iron salt, after which wash or let stand in water fifteen minutes. Dehydrate and treat with clove oil-orange $\mathrm{G}$. When the desired counterstain is reached, remove the oil with xylol, and mount in balsam, either with or without following the xylol with cedar oil. Care should be taken not to let the clove oil-orange $\mathrm{G}$ act too long, or the smaller chondriosomes may be rendered indistinguishable.

It will be seen that the latter process is shorter and simpler than the former. In some tissues prefer it to the crystal violet method.

\section{OBSERVATIONS.}

This paper will deal with the results obtained in the study of root-tips of Pisum sativum, Zea Mays, the thallus of Marchantia polymorpha, Anthoceros, Pallavicinia, the seedling of Pimus Banksiana, the stem and leaves of Elodea canadensis, and the root-tip of Adiantum pedatum, together with certain Algae.

Pisum. I began first with the root of the pea in order to verify observations of others and to test the usefulness of the methods employed. Sections were cut from three to five microns in thickness.

Pisum proved to be one of the most satisfactory objects for the demonstration of the transformation of primordia into leucoplasts. In the meristematic cells of the root, at the juncture of the root-cap and the tip of the root proper, one finds the structure shown in Plate I, Fig. 2. The most conspicuous objects in the cell, apart from the nucleus, are the numerous black rods (iron-alum-haematoxylin being used) occurring in relatively large numbers. These rods vary in length and thickness; they may be straight or variously curved or bent, while some present a lumpy appearance as if composed of granules. In this region of the root some of the rods show a globular thickening at one end. The rods sometimes show a tendency to accumulate about the nucleus and arrange themselves radially from it, but, as a rule, they are promiscuously scattered within the cytoplasm.

In addition to the large rods (Fig. 2) are numerous very small globular or granular bodies and very slender, delicate rods that stain the same colour and seem to be of the same ultimate composition as the large rods. The granules occur singly or in rows or chains of two or more. The very 
slender, delicate rods vary also in length and thickness. In fact, all of the bodies mentioned vary in form and size. Although under lower magnification the cells appear as if containing numerous rod-shaped bacteria, the rods and granules are very readily distinguished from bacteria, because of the uniformity in the size of bacteria and the smooth, clear-cut surface of their cell walls.

Passing back in the root to where the cells of both plerome and cortex begin to elongate, it is clearly seen that the larger rod-shaped bodies change gradually into those which take on the form of a club- or pearshaped body or that of a hand-mirror (Fig. 3). These are leucoplasts, and they contain one or more inclusions or starch grains. The starch grain, which represents the glass of the hand-mirror, remains colourless or may appear a pale blue, especially when crystal violet is used or if the destaining is not carried too far in the iron-alum-haematoxylin preparations. The protoplast, which corresponds to the handle of the mirror, stains a jet black (Figs. 3 and 4). It is quite evident, therefore, that the larger thick rods are the primordia of leucoplasts. A comparison of Figs. 2 and 3 will show how these primordia, of whatever length, are changed into leucoplasts. The transition takes place as follows: The rod becomes swollen or enlarged at one end, where a small and palely-staining starch inclusion is forming. The inclusion enlarges, becoming round or oval. The result is that the shorter rods become club- or pear-shaped leucoplasts, while the more elongated forms take the form of a hand-mirror. I do not regard the hand-mirror form as a division stage of the leucoplast. Fig. 3 shows also how numerous are the very delicate and slender rods and granules which do not become leucoplasts but retain their identity even in older cells of the root. These I shall designate as chondriosomes. Fig. 4 illustrates, more highly magnified, some of the commoner forms of the larger leucoplasts found in older cells of the root that have become greatly elongated. In Fig. $4, b$, the leucoplast contains three smaller starch grains. At $c$ (Fig. 4) a large, oval starch grain is near the middle of the leucoplast. Fig. $4, d, e$, shows other forms of leucoplasts with large starch grains, while at $a$ are shown a few of the very much smaller granules and rods that do not become leucoplasts. In these same cells are frequently found smaller and more rounded leucoplasts containing one or more rounded starch grains, as figured at $a$, Fig. II, for Pinus. These small leucoplasts are more difficult to stain than the larger and may be readily overlooked. In addition to the foregoing leucoplasts, the most conspicuous phenomenon in all cells of the root-tip is the presence of innumerable round or rod-shaped chondriosomes. These bodies do not form the groundwork of the cytoplasm, the latter being a much more finely granular or homogenous substance.

Passing now from the root-tip proper to the root-cap, we note that the 
rods become fewer, but there seems to be little or no falling off in the number of granules. Fig. I represents a cell from near the end of the rootcap, in which rounded starch grains are present in the distal end of the cell. The most conspicuous objects in the cytoplasm, even when examined with the ordinary high powers of dry lenses, are the numerous chondriosomes in the form of densely-staining granules, rows of granules, and rods. These objects, so numerous here as elsewhere, far exceed the number of starch grains that could be contained in any cell of the root-cap, and the conclusion is that they are not identical with leucoplasts. While it is not pessible to distinguish between the primordia of leucoplasts and the rods and granules that do not become leucoplasts, I have come to the conclusion, from the presence and behaviour of all these bodies in both young and older cells, that the primordia of leucoplasts are not the same as these other objects. This conclusion is borne out in the case of all other plants to be noted below, in which it will be shown that the primordia of chloroplasts are identical with those of leucoplasts and that it is probably better to confine the name chondriosome to the objects that do not give rise either to leucoplasts or to chloroplasts. Both chondriosomes and primordia of leucoplasts multiply by transverse division or constriction.

The rounded starch grains of the root-cap reveal the plastid as a narrow, darkly-staining crescentic or rounded body at one side, although the plastid doubtless surrounds the whole starch inclusion. These starch grains were developed from the smaller rounded or rod-shaped plastids. Lewitsky (1910) figures a cell from the root-cap of Asparagus officinalis (his Fig. I8) in which similar starch grains are shown, but these bodies are designated in the description of the figure (1910, p. 546) as 'Statoblasten'. In the drawing he does not show the plastid. While some of the leucoplasts in the root-cap and in other parts of the root, as in the cortex, are derived from rounded primordia, yet the transition of the short rod through the club- and pear-shaped forms is easily observed.

In the elongating cells of the vascular cylinder of the root, the primordia of leucoplasts are apparently more numerous and longer than in cells of the cortex. All of the primordia do not develop starch inclusions; those that do not become long and frequently thread-like. They finally undergo disorganization in older elements. In the cortex of the root the primordia seem to be generally shorter than those of the central cylinder.

Zea Mays. As a second phanerogamic root-tip, that of Zea was chosen.

In the meristematic cells of the tip, including those of the root-cap, or calyptrogen, are numerous densely-staining granules and rods somewhat evenly distributed in the groundwork of the cytoplasm. These bodies are smaller than in the root of Pisum. The granules are by far the more 
numerous. Some of the granules present a smoother contour than others. The rods vary in length, and to some extent in thickness. Some are clubshaped and some dumb-bell-shaped. In cells of the root-cap the rounded granules far exceed the rods in number as in Pisum. In the older parts of the root-cap, where the cells have begun to round off and separate from each other, rounded leucoplasts with their starch inclusions are present and confined chiefly to the distal ends of the cells, although a few are distributed throughout the cell. The transition of the short rod-shaped primordia, through club-shaped, pear-shaped, and hand-mirror-like forms, so conspicuous in Pisum, is not so easily observed in the root-cap of Zea. Some of the leucoplasts arise from rounded primordia, these appearing at first only slightly larger than the densely-staining granules, but with a sharp contour or rim and a colourless, or only slightly stained, centre. In $Z e a$ such very small leucoplasts are present in small numbers in the meristematic cells. In cells of the dermatogen and plerome, the transformation of rod-shaped primordia through the forms just mentioned is conspicuous. As in Pisum, there are also present, in addition to the primordia, the very numerous rounded chondriosomes. They persist in large numbers even in older cells. The behaviour and fate of both plastids and chondriosomes is the same as that described for Pisum.

Marchantia. No other plant selected by me for study shows more clearly the sharp and well-defined difference between chloroplasts and the rod-shaped or granular bodies which are not chloroplasts and which do not develop into chloroplasts, but which reveal and retain their identity in both young and old cells.

In Fig. 5 we have a longitudinal vertical section through the growing point of the thallus, including one apical cell and two young ventral scales. In the apical cell, and in those touching it, are to be seen the young rounded chloroplasts and the very small rod-shaped and granular bodies. The groundwork of the cytoplasm is illustrated by fine stippling. In older cells, removed two or three layers from the apical cell, the difference between the rounded chloroplasts and the rod-shaped chondriosomes is more obvious. Fig. 6 is a cell taken a little farther back from the growing point than those in Fig. 5. Here some of the chloroplasts appear more rounded and larger, probably with a flat side turned towards the observer. Others are narrower and lenticular in shape with a light strip running lengthwise through the middle. In this position the chloroplasts present a view not unlike the flattened side of a grain of wheat or a coffee bean (see also Fig. 6). The chloroplast in these cells seems, therefore, to be a flattened object, round, oval, or elliptical when viewed from the flat side, but somewhat lenticular when seen from the edge. In older parts of the thallus, the colourless, lenticular centre is, doubtless, an inclusion of starch. In some instances the chloroplasts in older cells present the appearance of Fig. I4, a, 
in which there seems to be more than one starch inclusion. This is especially true in young gemmae, in certain vegetative cells of the antheridiophore, and elsewhere. Such chloroplasts probably contain two or more starch grains or small masses of starch, and in this respect chloroplasts and leucoplasts seem to be alike. The nucleus (n, Fig. 6) has a very delicate nuclear membrane, with the chromatin in the form of small, rounded granules, as may be seen also in cells of Fig. 5. Fig. 7 presents a cell beneath a dorsal air-chamber. In the living thallus such cells appear green with numerous large, well-developed chloroplasts. The chloroplasts here stain a deep blue with the crystal violet and present a uniform, homogeneous structure. This is the usual behaviour of mature chloroplasts rich in chlorophyll. In these and similar cells (Fig. 7) the chloroplasts show the usual division stages. In such cells the chondriosomes likewise show division stages (Figs. 6 and 7). If we now turn to still older cells in the thallus, we have the structure presented in Fig. 8, which represents a tangential view of the cell. The chloroplasts are smaller and irregularly distributed along the periphery of the cell. The scanty cytoplasm is omitted from the figure. They are rounded or somewhat lenticular, as described above. The majority of the chondriosomes are in the form of delicate rods of varying length. Some seem to be dividing. In preparations stained with iron-alum-haematoxylin, the chondriosomes appear black, while with the crystal violet their colour is a beautiful deep blue. In such cells the chondriosomes stand out so clearly that the preparations make most excellent objects for the demonstration of both the chloroplast and the chondriosome.

Taking the thallus of Marchantia as a whole, we find chondriosomes in all cells. In the apical cells and their immediate neighbours, the chloroplasts and their primordia are small, but, as a rule, readily distinguished from the smaller granular or rod-shaped chondriosomes. In the isodimensional cells not far removed from the growing point, the chloroplasts begin to assume their adult form, being much larger. The chondriosomes are, however, larger and more sharply defined than at the growing point, but always in the form of granules or rods. Many are seen in process of division. Short rows of granules are found here also. In the dorsal chlorenchyma layer, chondriosomes are relatively few, but they are thicker than in deeper parts of the thallus. Those of the cells forming the floor of the dorsal air-chambers are relatively larger than in other cells below them (Fig. 7). The older cells near the centre of the thallus have apparently few chloroplasts, but many slender, rod-shaped chondriosomes that vary greatly in length, along with those that may be spoken of as very short rods or granules. Many of these rods and granules show constrictions in the middle as if in the process of division (Fig. 8). The division stages in younger cells present the same appearance. In much older parts of the 
thallus, chloroplasts and all other contents of the cell present conclusive evidence of disorganization.

It is, however, in the mucilage-producing hairs borne by the ventral scales and springing from the floor of the gemma cups, and in the young rhizoids, that chondriosomes find their greatest development. The large mucilage hair (Fig. 5, a) presents the usual structure of such cells at that age. In the rather dense cytoplasm the numerous rods and granules are strikingly conspicuous. Many of the rods are long, exceeding the greater diameter of the nucleus. Some of the rods show clearly that they consist of a row of very small granules. In the younger mucilage hair (Fig. $5, b$ ) the cytoplasm is very dense, and the chondriosome primordia are smaller. There are no chloroplasts in the larger hairs, and in the youngest all staining bodies distinguishable in the uniform groundwork of the cytoplasm are minute. Whether chloroplast primordia are present here, I am not able to say with certainty. The cells of the young ventral scales bearing such mucilage hairs show the usual chloroplasts and chondriosomes, which are clearly and sharply differentiated.

Perhaps one of the most striking parts of the thallus is seen in the young rhizoids (Fig. 9). The chondriosomes are very large and extremely numerous. In thick sections the whole cell seems to be filled with the blue or black rods and granules. These rods and granules show the characteristic division stages. No recognizable chloroplasts are evident at this stage of the hair's development, although the cells of the ventral epidermis, from which the hairs develop, contain chloroplasts. Whether any of the bodies shown in Fig. 9 are disorganizing chloroplasts I am unable to state. As the rhizoids mature, all cell contents gradually disappear.

The mucilage hairs arising from the base of the gemma cups and in the antheridial cavities do not contain chloroplasts but very numerous chondriosomes, although these are smaller than in the mucilage hairs borne by the ventral scales and by the young rhizoids.

The methods of fixing and staining used here bring out clearly the progress in the formation of mucilage or slime in the so-called mucilagebearing cells of the thallus of Marchantia. The mass of slime first appears in the centre of the cell. It presents a very fine, uniformly granular appearance, staining a greyish, bluish, or brownish colour, depending upon the intensity of primary staining with the haematoxylin or violet and the counterstain with the orange $G$. As the mass of mucilage increases, the cytoplasm, together with the nucleus, chloroplasts, and chondriosomes, are crowded into a thin layer along the cell wall. The entire living content of the cell is finally used in the formation of the slime.

The mucilage excreted by mucilage hairs in both gemma cups and antheridial cavities, for example, seems to be of quite a different composition. In the latter case, no trace of mucilage can be seen inside these 
hairs. The mucilaginous substance surrounding the young gemmae stains a beautiful light brown with the orange $G$. It is a perfectly homogeneous and structureless mass.

In all developmental stages of a gemma, chondriosomes, along with the chloroplasts, are present in the cells. The large stalk cell of the gemma contains relatively few chloroplasts, but the chondriosomes are conspicuously numerous.

In the early stages of antheridial development, the chloroplasts are eliminated from the central cells that give rise to the spermogenous tissue, being confined to the wall of this organ. In the wall cells both chloroplasts and chondriosomes are present, but only the latter in the spermogenous tissue. In all stages of antheridial development, chondriosomes are numerous and conspicuous in the spermogenous tissue up to the time of the final and diagonal division of these cells. They are in the form of granules or very short rods. Their fate was not traced in the transformation of the cell into the sperm following the diagonal division.

Anthoceros. Inasmuch as the cells of Marchantia contain a number of chloroplasts, the question naturally arose as to whether the chondriosomes were not merely products of the disorganization of chloroplasts, or, in meristematic cells, undeveloped primordia of chloroplasts. In order to compare the chondriosomes described in the foregoing for Marchantia with those of a plant with one chloroplast to the cell, a study of the thallus of Anthoceros laevis was made. Scherer (1913, p. 497) states that during the entire development of the gametophyte of Anthoceros Husnoti every cell, with the exception of the apical cell, possesses one chloroplast and a larger or smaller number of chondriosomes.

My observations were made on the gametophyte of Anthoceros laevis. In all parts of the plant studied I am able to confirm the results of Scherer and to extend his conclusion to the apical cell as well. In the apical cell (Fig. I3), as in other vegetative cells of the thallus, the chondriosomes are very small and difficult to demonstrate, appearing, for the most part, as very slender and delicate rods or granules. They are relatively smaller than those of Marchantia and fewer in number in the ordinary cells. In the cells of the wall and stalk of the antheridia, on the contrary, the chondriosomes are larger and more conspicuous and retain the stain with greater avidity. I am also able to confirm the observations of Scherer in regard to the presence of chondriosomes in the spermogenous tissue and in the egg cell of the archegonium. The chondriosomes as figured by Scherer (1. c., Fig. 9) for cells of the spermogenous tissue are quite similar to those mentioned in the foregoing for Marchantia. In an early stage of the transformation of the sperm, a conspicuous rod is seen in each cell along with the nucleus. This I interpret as the blepharoplast. I was not able to convince myself that chondriosomes were present in such cells. 
Since there are always several chondriosomes in spermogenous cells at earlier stages in the antheridium, it is extremely doubtful whether the blepharoplast, which is preserved in fixing solutions containing acetic acid, represents a chondriosome.

The fear that chondriosomes may be products of disorganized chloroplasts disappears entirely in the case of Anthoceros, since each cell reveals its conspicuous chloroplast, in which there appears no sign of disorganization.

It may be worthy of note that the technique, as here employed in the study of chondriosomes, is well suited to bring out the structure of the chloroplasts, together with their contained collection of rod-shaped or granular pyrenoid bodies described by McAllister (1914). The pyrenoid bodies, in form and staining reaction, bear some resemblance to the chondriosomes which are present in the stalk cells of the antheridia. These pyrenoid bodies are, as a rule, larger and stain more densely than chondriosomes found in the vegetative cells of the thallus.

Pallavicinia. In the cells of this liverwort, which contain many chloroplasts, chondriosomes are present, especially in the meristematic region, although they occur also in the large cells some distance removed from the growing point. In form they are similar to those of Marchantia, being, however, smaller and less numerous. In the large apical cell, in which the relatively small chloroplasts stand out with striking clearness, the chondriosomes are few, and in the form of small rods that do not stain deeply. As in the apical cell of Anthoceros they are difficult to bring into evidence and may readily be overlooked. In the middle of the thallus, about four or five cells back of the apex, small round or globular chondriosomes were found to be numerous in some preparations. In the older cells of the thallus they appear, when stained with crystal violet, as very pale blue slender rods or threads. The paucity of chondriosomes in the hair-like outgrowths of the growing end of the thallus presents a striking contrast to the large numbers found in similar structures in Marchantia.

Adiantum. In this plant the following statements will be confined to the results obtained in the study of the root-tip, while a discussion of the presence and behaviour of chondriosomes and plastids in other organs of the fern will be reserved for a future publication. The tips of fresh young roots about one centimetre long that had developed directly from the growing end of the stem were selected for study.

In the apical cell there are to be recognized two apparently different and distinct primordia: small granules and rods that stain densely and uniformly, and larger bodies which are chiefly lenticular in shape. The former correspond to chondriosomes, as used in this paper, and the latter are clearly the primordia of the leucoplasts (Fig. I3). These leucoplast primordia present the same form and structure as certain chloroplasts in 
the liverworts and other plants studied, being, as stated, lens-shaped with a colourless or less densely stained lenticular centre, especially after staining with crystal violet. If vacuoles be present in such cells, both classes of bodies are mainly aggregated about the nucleus.

Passing from the apical cell into the root-cap, it is seen that in the young cells of the root-cap, namely, the last segment cut off, or the two or more cells resulting therefrom, the primordia of leucoplasts are perceptibly larger and stain densely. In the third and fourth layers of the root-cap, they show a further increase in size, and, in crystal violet preparations, the pale or colourless lenticular centre is more pronounced. In the fifth layer the typical cell contents are shown in Fig. $\mathrm{I}_{4}, b$. The leucoplasts are usually lenticular or elliptical in shape. The almost colourless lenticular centre gives the impression that these bodies are hollow or contain an inclusion which stains only slightly. The chondriosomes consist mostly of small granules or short and more delicate rods.

In this layer of cells of the root, some of the leucoplasts are seen to contain two lenticular inclusions. In the sixth and seventh layers of the root-cap in question, all leucoplasts stain poorly with both the haematoxylin and the crystal violet. Each contains from one to three or four lenticular inclusions, as shown in Fig. I4, $a$. In the eighth and outermost layer of this root, the cells are beginning to separate from each other, and signs of disintegration are very apparent. The leucoplasts and their inclusions have disappeared from certain cells, but even in these the small granular and rod-shaped chondriosomes are very numerous; they are among the last of the protoplasmic contents to disappear from these cells.

In the cells of the root-cap, as well as in many of those of other parts of the root, especially in the cortex, there is present a cluster, or clusters, of rounded bodies of varying sizes which do not take the violet or haematoxylin stains readily, but which stain a pale orange with the clove oilorange G (Fig. I4, b). As nearly as can be determined, these clusters seem to be plastids with partly digested starch inclusions. In many of the cells of the cortex and older parts of the plerome cylinder these pale orangecoloured clusters are conspicuous, appearing in contrast with the larger plastids with their inclusions, which vary in colour from a pale blue to a light or smoky grey in preparations rather densely stained with haematoxylin. In many cells of the outer cortex, as we pass back into the older parts of the root, the pale orange-coloured bodies are the only objects of the cytoplasm present in addition to the chondriosomes. The probability that they are the products of the plastids is strengthened by the fact that they are among the last structures to disappear in disorganizing cells of the root-cap and in those of the older parts of the root.

Passing back from the apical cell to the body of the root, we find, in the latest segments cut off, that the primordia of the plastids and chondriosomes 
are of the same size and structure as in the apical cell. In the cells resulting from the second or third older segments, the primordia, now larger and more numerous, stain very densely. In slightly older cells some become club- and dumb-bell-shaped. In cells of the central cylinder, a little farther back, the densely staining rods are the most strikingly conspicuous objects in the cell. This is well illustrated in Fig. I5. Here it is seen that the rods vary in length, many being variously curved or bent. In addition to the rods, which are unquestionably derived from the primordia of plastids seen in the apical cell, there are the ever-present granules in countless numbers. They occur singly, in pairs, as if in division, and in chains. These granules do not constitute the groundwork of the cytoplasm (Fig. I5). In the narrow elements of the central cylinder of the root, which have dense cytoplasm, the rods are numerous and especially conspicuous, because they are thicker and stain densely. Many seem to be undergoing transverse division, but whether they break up into the small granules cannot be stated with certainty. The leucoplasts in the form of a hand-mirror, which are rather conspicuous in Pisum, are very rare in the fern and of a much smaller size.

In the wider elongating cells of the central cylinder, which have sparse cytoplasm, the rod-shaped primordia of leucoplasts that fail to develop inclusions become greatly elongated and flattened threads staining a pale blue (Figs. I6, I 7). They are undergoing disorganization, for in older cells they disappear. Figs. $I 6$ and $I 7$ represent tangential views of portions of two large cells of the central cylinder. In addition to the long and disorganizing threads are the very numerous small rods and granules, the chondriosomes, which are present in younger parts of the root and which do not seem to be derived from the plastids nor from the conspicuous rods that develop from the plastids. In Fig. 17 , at the left, is seen a cluster of starch grains which, together with surrounding cytoplasmic granules, stain a pale orange. The group is the same as those described in a preceding paragraph for cells of the root-cap.

The plastid primordia in the younger cells of the periblem and dermatogen are identical with those of the central cylinder, but in this region, as the cells begin to elongate and enlarge, the primordia do not become long rods. These cells present a striking contrast, therefore, to those of the central cylinder with their numerous densely stained rods. In these periblem cells some of the primordia develop into rounded leucoplasts with starch inclusions; others remain as they appeared in the younger cells. The small, densely-staining round chondriosomes, conspicuous as black or blue dots, are present in large numbers in both old and young cells of the periblem as elsewhere. In older cells of this region there remain in the cytoplasm the yellowish-staining clusters of starch grains, a few isolated leucoplasts, pale in colour, and the numerous round chondriosomes. 
It seems reasonable to conclude from the foregoing that in the growing root-tip of Adiantum there are two distinct organs in the cytoplasm, namely, the primordia of plastids and other bodies, which I have spoken of as chondriosomes. The latter vary in shape from spherical granules to short, delicate rods, the former always exceeding the latter in number. They divide rapidly with the growth of the cell, thereby becoming very numerous, especially in the large, rapidly elongated cells of the central cylinder. The primordia of leucoplasts, on the contrary, develop in the root-cap into bodies resembling certain chloroplasts, which contain one or more lenticular inclusions of starch. In the root proper these primordia remain in their original form as small, elliptical bodies, or develop into starch-bearing plastids, or in the plerome cylinder they may become large, elongated rods, which do not give rise to leucoplasts but continue to elongate into long-drawn-out threads which finally disappear.

Pinus. In the Gymnosperms, the young seedlings of Pinus Banksiana that did not exceed a centimetre in length supplied the material for study. In the cells of the growing point of the stem all primordia of cytoplasmic differentiations are small. Two kinds may be recognized in the groundwork of cytoplasm, which appears as a network in preparations stained with the haematoxylin method,-namely, very small round or globular bodies with a colourless centre, which may be represented by drawing a very small circle with a hard pencil, the primordia of leucoplasts and chloroplasts, and very small, densely-staining black specks, those of the chondriosomes. Passing to older parts of the seedling, as, for example, to the cortex of the young stem or to the cotyledons, we see that the circular and almost colourless primordia develop into the chloroplasts or leucoplasts, while the denselystaining bodies, which appeared as minute black specks, have become larger granules or rods, as shown in Fig. 10. I have not been able to convince myself that these minute bodies ever develop into leucoplasts or chloroplasts. The large densely-staining rods, so conspicuous in the roots (Figs. 2, I5), are not present in the parts of the seedling observed. The chloroplasts in such cells are rounded, oval, or lenticular bodies with colourless inclusions. In some the inclusion constitutes the bulk of the object; in others it is smaller, lying near one end. The form of the individual chloroplasts differs somewhat in the same and in different cells. In some cases they seem to be thinner and flatter; in others, thicker and more rounded. It cannot be stated with certainty that the lenticular form is merely an edge view of a flattened, oval, or rounded chloroplast as seems to be true in some cases. The small, densely-staining, and homogeneous granules and rods are very numerous in the cortical cells of the stem and the cotyledons (Fig. IO). Their number seems to vary considerably, however, in different cells. Both rods and granules seem to multiply actively by division, for division stages are readily observed. It seems reasonable to 
believe that the rods represent rows of granules closely united, which may separate into granules. As to this, I am not thoroughly convinced. While the round bodies are much more numerous, yet rods usually occur, and some of these rods present a perfectly homogeneous structure, not only here but also in the other plants included in this study.

Deeper in the stem, near the base of the cotyledons, the chloroplasts present the form shown in Fig. II, $a$. They are similar in form, being a trifle larger. One or two inclusions may be present. The inclusion, or inclusions, may be relatively small, occupying one end of the plastid, or larger, entirely filling it. Passing now to the outer part of the cortex of the stem, the chloroplasts are seen to be much larger, rounded or polygonal, and somewhat crowded (Fig. II, $b$ and $c$ ). These full-grown chloroplasts stain very densely and present a homogeneous structure, save for the presence of one or more inclusions. In the large, polygonal chloroplasts the two or more rounded inclusions are either grouped near the middle or at one side, or somewhat scattered. The smaller and rounded chloroplasts contain, as a rule, but one inclusion located at one side (Fig. I , $b$ ). At $b$, Fig. I I, are shown five small rounded bodies which are derived from the small rods and granules shown in Fig. 10, namely the chondriosomes. They vary in size and in number in different cells. In cells of the enlarging cotyledons, in which large intercellular spaces have begun to be formed in the chlorenchyma, the cells, rich in large chloroplasts, contain relatively few chondriosomes. In the cells of the elongating hypocotyl, and especially those of the cortex, the chondriosomes are especially numerous.

It may be stated here that in none of the objects used in this study have I found chloroplasts in the form of the conventional rounded or elongated object with a dense body in the middle called a pyrenoid. The nearest approach to the conventional chloroplast is seen in Fig. II, $c$, which shows a large chloroplast in division. In the cortex of the hypocotyl, division stages of the large chloroplasts are frequently met with. Deeper in the hypocotyl, the leucoplasts or chloroplasts usually present the form of Fig. II, $a$. Along with these, there are present those that are club-shaped, or pear-shaped, or in the form of a hand-mirror.

Elodea. A study of the stem and young leaves of Elodea canadensis was made in order to compare my findings with those of other observers.

Cells of the base of young leaves present an appearance not unlike those of certain root cells of Pisum, Adiantum, and $Z c a$, as shown in Figs. 2 and I5, the large, densely-staining, rod-shaped primordia of the chloroplasts being, apart from the nuclei, the most conspicuous objects in the cell. Lewitsky gives a good representation in his Figs. I and II $(2,1911)$. Some of these bodies are dumb-bell-shaped, as stated by Lewitsky, and are undoubtedly undergoing division. Many are also club-shaped. In addition, 
there are present small globular granules, as described above for the other plants.

In successively older leaves it is quite easy to trace the transformation of these rods into the chloroplasts in passing from the base up into the leaf, and into leucoplasts, from the base of the leaf into the cells of the node of the stem. The series of changes into chloroplasts is almost identical with that described for the leucoplasts in the root of Pisum.

Passing into the leaf, these rods become oval, pear-shaped, or clubshaped, and many take the form of a hand-mirror. These various forms owe their existence to an increase in size and especially to the accumulation of an inclusion. The inclusion is starch, as can be readily demonstrated in the fresh leaf by the iodine test. The inclusion stains very slightly or not at all with haematoxylin. The starch inclusion may lie, for example, in the centre or in the broad, or sometimes in the narrower, end of the oval or pear-shaped chloroplast. Some are in the form of a dumb-bell with an inclusion in each end ; these are division stages. Towards the tip of the young leaf, and in older leaves, the vast majority of the chloroplasts are oval or rounded, with the other described forms intermingled. In some cases the lightly-stained inclusion represents the bulk of the plastid, while the densely-staining part appears as a narrow rim thickened at one side into a crescent. This can be verified in the fresh leaf by means of the iodine test.

As the chloroplasts become older, the inclusion stains more densely, giving the chloroplast a more homogeneous appearance throughout. Many chloroplasts show two or more inclusions. It will thus be seen that the development of the chloroplast from the rod-shaped primordium corresponds, in a large measure, to the same in Pinus. The fully developed chloroplasts may undergo division as well as their primordia, division stages being readily observed.

In the cells of the developing leaves, in addition to the chloroplast primordia, there are present numerous very small globular and rod-shaped bodies which do not develop into either chloroplasts or leucoplasts as described and figured in the foregoing for the other plants. These bodies are usually very numerous in cells of the leaf containing fully-developed chloroplasts. They are mainly globular, but many are in the form of delicate, short rods. They stain densely and uniformly in the cells in question. To these bodies I prefer to restrict the term chondriosomes in this plant.

Passing from the base of the leaf into the nodal cells of the stem, the same transition of densely-staining, rod-shaped primordia into the leucoplasts is seen, with the difference that the change from one to the other is more abrupt. The starch grains are circular, surrounded by a very thin layer of the plastid, which, however, may be widened at one side, appearing, 
if sufficiently stained, as a narrow crescent. The size and staining capacity of these starch grains vary in different preparations, depending probably upon the condition of nutrition in which the plants were when killed for study.

In the axillary scales of Elodea canadensis plastids are not well developed, very few chloroplasts or leucoplasts being present in the preparations. The two kinds of primordia, namely, small granules and rods, are very numerous. In certain cells of these axillary scales, some of the rod-shaped primordia develop into rather long and smooth rods or rods made of rows of small granules, which stain black with haematoxylin, not unlike those found in the mucilage hairs of Marchantia (Fig. 5).

In the meristematic cells of the stem-tip of Elodea, two sorts of primordia are present in the homogeneous groundwork of the cytoplasm, namely, very minute round bodies and slender rods. The rods are very conspicuous in well-stained preparations. As in meristematic cells of other plants, they vary in length and thickness, some being robust, and others very slender and delicate. Some seem to consist of a row of densely-staining granules. The transformation of these rods into chloroplasts and leucoplasts has been described in the foregoing. The minute round bodies stain palely and have a colourless centre. They may be represented by simply making a small circle with a hard pencil. Their periphery seems to be rather firm for so small an object, and that fact enables one to detect their presence. In older cells of both leaf and stem they are somewhat larger and very numerous, and they stain densely and uniformly. They appear now to be globules or very short rods of uniform structure ; for many become elongated into short rods which may be, as a rule, about two to four times as long as thick. In older cells of the leaf with well-developed chloroplasts, these granules and short rods lie among the chloroplasts and stain like them. Both rods and granules divide by.fission like mature chloroplasts or their primordia. As mentioned in an earlier paragraph, both sorts of primordia may be seen in fresh cells of young leaves that have been treated with iodine in potassium iodide solution.

Hydrodictyon. Space will permit of only a brief reference to findings in this plant. In cells of healthy, growing, though immature, individuals, the technique here employed revealed numerous round, or apparently globular, bodies remaining densely stained with the haematoxylin when other cell contents were colourless as a result of destaining. Since there are no individualized chloroplasts in the species in question, and the starch formed is clustered about the easily recognized bodies that pass as pyrenoids, there is no danger of confusing primordia of plastids with these bodies, which, for the time being, may be designated as chondriosomes. They are to be seen in the live cells as round, highly refractive bodies.

A further discussion will be reserved for subsequent publication. 


\section{DisCUSSION.}

A number of investigators (Guilliermond, Lewitsky, Rudolph, Forenbacher, and others) are now agreed that, in the higher plants studied by them, both leucoplasts and chloroplasts are developed from round or rodshaped primordia which may be readily observed in meristematic tissues, either in the living state or after the application of certain definite fixing and staining procedures, and which have been referred to as chondriosomes. It is also to be inferred from the literature that leucoplasts and chloroplasts are morphologically the same-a conclusion substantiated by the facts. But as to whether these primordia of chloroplasts and leucoplasts are permanent organs of the cells, having morphological rank, there is doubtless much difference of opinion. A number of observers have confined themselves chiefly to these primordia, while others have mentioned, in some cases only incidentally, the presence of other bodies which do not develop into chloroplasts or leucoplasts. Forenbacher, who has described the transformation of chloroplasts and leucoplasts from their primordia in the stem and root of Tradescantia, merely mentions the fact, without further comment, that other bodies are present in the cells, which are morphologically like chondriosomes (1911, p. 658): ' Es ist erwähnenswert, dass ich immer sowohl im Stengel wie in der Wurzel neben den schon entwickelten Chromatophoren noch Gebilde, die morphologisch mit den Chondriosomen vollkommen übereinstimmen, vorfand.' As to the morphological individuality of the primordia of leucoplasts and chloroplasts Forenbacher is non-committal (1911, p. 660).

On the other hand, Rudolph (1912) and Sapěhin (1913) distinguish between the primordia of plastids and other bodies that do not develop into either chloroplasts or leucoplasts. Rudolph is strongly inclined to the view that chondriosomes and the primordia of plastids are entirely different structures. In his summary $(1912$, p. 626$)$ he says that in the primary meristem of the growing point (speaking of the stem of Asparagus officinalis) there are present chiefly granules varying in size. Elongated forms are mixed in among them, occurring singly, but these may be regarded as division stages. Some of the granules increase rapidly in size, multiply, and change into chloroplasts and leucoplasts. The division stages are at times, even in older tissues, elongated so that the rod-shaped forms approach those which are filamentous in form with swollen ends. These are especially abundant in the elongated elements of the vascular bundles. However, all transitions to normal division stages are present. The remainder of the granules of the meristematic cells persist in their original form, multiply as the cells divide, and thus become distributed to all cells. Out of these are formed threads varying in length, which become more numerous as we leave the growing point. It is probable that the threads represent incompletely 
divided chains of smaller granules. These structures are designated by Rudolph as chondriosomes (Mitochondrien, Chondriokonten, Chondriomiten). In the mature cells of pith and cortex, he continues, are to be seen side by side full-grown chloroplasts and chondriosomes without transitional stages. In the elongated cells of the vascular bundle and accompanying tissue, the long-drawn-out division stages of chromatophores may deceive one as to transitions. It seems more probable that chondriosomes and chromatophores (he doubtless means here chloroplasts and leucoplasts), though alike morphologically and in staining properties, are structures of a different nature without any genetic connexion existing between them. In no case are chondriosomes changed into chromatophores.

From the foregoing summary of Rudolph, it is clear that he recognizes two forms of primordia in the meristematic cells of the stem-tip, namely, granules and rods. He regards the rods as probable division stages. Some of the granules increase rapidly in size, multiply by division, and change into leucoplasts and chloroplasts. The long, conspicuous rods, some with swollen ends, which are numerous in the elongating cells of the vascular bundle, are also regarded by Rudolph as division stages. These he calls chondriosomes. He does not show how a leucoplast arises, and the small, conspicuous, rounded granules in these cells are referred to in his description of Fig. 6 as 'Mitochondrien, Chondriokonten und lange Chondriomiten'.

Sapěhin (1913), using the Mosses Polytrichum, Funaria, Byrum, and Mnium as objects of study, distinguishes clearly between plastids and chondriosomes, concluding that these two bodies are quite independent structures. He strongly supports the doctrine of the individuality of plastids. In almost all cells of gametophyte and sporophyte (1913, p. 323) he finds both chondriosomes and plastids. The former occur as granules or delicate, slender rods of varying length.

In the closing paragraph of this paper, Sapehin makes the astonishing statement that in the Characeae, Bryophyta, and Pteridophyta the structures known as centrosomes and blepharoplasts are merely plastids.

Guilliermond has published numerous short papers on chondriosomes, in which are presented the results of his observations made upon various higher plants and several fungi. He applies the term chondriosome (mitochondria, chondrioconte) to the primordia of leucoplasts and chloroplasts and to the bodies of similar form to which he attributes the formation of anthocyanin in higher plants, and to the rods and granules in the Yeasts and a number of other fungi, which, he asserts, give rise to metachromatin granules and fats. In his earlier papers Guilliermond $(2,3,4)$ describes the formation of leucoplasts and chloroplasts from their chondriosome-like primordia. A number of his later papers $(8,10,13,14)$ are devoted to the origin of the pigments, anthocyanin, xanthophyll, and carotin of certain 
plants. In one instance he refers to leucoplasts occurring in the same cell with numerous filaments or rods impregnated with anthocyanin. Referring to the epidermis of the young petals of Iris germanica, at a stage when the cells poscess a central vacuole containing anthocyanin, with the cytoplasm and nucleus confined to a peripheral layer, he says (I 3 ): 'Dans le cytoplasme on distingue, en dehors des chondriocontes en voie de se trans. former en leuco- ou chromoplastes, de nombreux filaments ou bâtonnets imprégnés d'anthocyane.'

Guilliermond was among the first to ascribe to the bodies which he designated as chondriosomes the morphological rank of unity equal to that of the nucleus.

Anthocyanin, according to Guilliermond ( 13 ), is formed, owing to circumstances, either directly as a pigment within the chrondriosome or from colourless phenol compounds by oxidation.

Löwschin (1914), in the young leaves of the rose, and Mirande (1916), in those of Azolla filiculoides, trace the pigment, anthocyanin, to its origin in chondriosome-like primordia, although these observers differ somewhat in regard to the precise manner in which the pigment is produced.

In certain Ascomycetes and Basidiomycetes, and in the Yeasts, numerous granules and rods are present in the cells of the mycelium and conidia (Penicillium), in the ascus (Pustularia), and in the basidia of certain autoBasidiomycetes. In Endomyces Magniesii long rod-shaped bodies are found, with colourless inclusions, in the enlarged end, giving the body the form of a club, and bearing a strong resemblance to the primordia of a leucoplast with a starch inclusion. In the fungi also Guilliermond considers the ' chondriosome comme un élément constant et indispensable de la cellule, au même titre que le noyau' (1913, p. I784).

Janssens and Van de Putte (1913) describe and figure numerous large rods, granules, and rows of granules in the young ascus of Pustularia vesiculosa, which bear a striking resemblance to the chondriosomes described in the foregoing for Marchantia. When the ascospores are formed, many of the rods and granules are included in them. Likewise, relatively very large rods and granules are described in the cells of the yeast Saccharomyces cerevisiae, by Janssens and Helsmortel (1913).

It seems now well established that the primordia of both leucoplasts and chloroplasts are morphologically alike. If a difference exists, it is not possible at present to distinguish one primordium from another. I am also convinced that these primordia are morphological units of the cell, with the same rank as the nucleus. In addition to these primordia, there is also another organ of the cell to which I have restricted the term chondriosome. These are morphologically distinct from leucoplasts and chloroplasts and are to be regarded also as permanent organs of the cell.

If we are now justified in the view that leucoplasts, chloroplasts, and 
chondriosomes are organs of the cell, of the same rank as the nucleus, it follows that these bodies must be transmitted from individual to individual in the form of their primordia and that the chromatin is not the sole carrier of the hereditary characteristics. In my own opinion such a view does not impair one's faith in the doctrine that the nucleus is the chief vehicle of hereditary characteristics, but it does not give the nucleus the monopoly in heredity. There is no sufficiently convincing evidence that the primordia of the plastids and the chondriosomes are carried within the cavity of the nucleus. They must occur in the cytoplasm of both gametes in all plants. Even in such plants as Bryophytes and Pteridophytes there is always enough cytoplasm in the sperm to contain these primordia; so there is no likelihood of their being omitted from any gamete.

The very important question now presents itself: What characteristics are transmitted solely by the nucleus, and what by the primordia of plastids and by chondriosomes? How do these respective characteristics behave in heredity? It is probably admitted on all sides that such characters as are known as Mendelian are carried by the chromatin, but chromatin does not carry chloroplasts, leucoplasts, or chondriosomes. There are many transmissible characteristics that cannot as yet be definitely expressed in any Mendelian ratio. To claim that certain phenomena of fluctuating variability and other numerous characteristics, Mendelian or otherwise, owe their appearance and transmission to the primordia of plastids and chondriosomes may be a daring hypothesis, but, if, as there is good ground to believe, these bodies are permanent organs, there is no escape from some such assumption. If, as some have attempted to show, the pigments grouped under the term anthocyanin are due to a definite granular or rod-shaped body, which is a permanent organ of the cell, are we to conclude that colours, whether behaving in the Mendelian ratio or not, are transmitted by the nucleus? Naturally we are not to think of nucleus, plastids, and chondriosomes as bodies working wholly independently of each other and of the remainder of the living substance, which we call the groundwork of cytoplasm. A nucleus is not known to operate outside of the cytoplasm, nor can these other bodies have any functional existence outside of the cytoplasm. It is, of course, idle to speculate, but nothing is clearer to the biologist to-day than that the living substance has a much greater complexity than was formerly attributed to it. There was a time not very remote when cytologists were somewhat content to believe that dilute solutions of certain acid or alkaline combinations were sufficient to reveal every part of the cell contents visible to high powers of the microscope. At present it is known that while certain parts of the cell are beautifully revealed by the use of certain reagents, other parts are destroyed or rendered unrecognizable by these reagents. Varied and complex phenomena have their basis in varied and complex morphological entities. 


\section{SUMMARY.}

I. Leucoplasts and chloroplasts are derived from granular or rodshaped primordia which are morphologically alike and which are permanent organs of the cell, with the same rank as the nucleus. These primordia multiply by division. Full-grown chloroplasts multiply also by division.

2. In the cells of Anthoceros, Marchantia, and Pinus, and in the tissues of the other higher plants mentioned in the foregoing "pages, there are present in the groundwork of the cytoplasm granular and rod-shaped bodies which do not give rise to either chloroplasts or leucoplasts, and to which the name chondriosome is restricted. These chondriosomes multiply by division, and they are permanent organs of the cell.

3. Chondriosomes, as well as the primordia of leucoplasts and chloroplasts, are concerned in the transmission of certain hereditary characteristics.

4. The function of chondriosomes in the cell cannot be definitely formulated at present. They are probably concerned in certain processes of metabolism.

\section{LITERATURE REFERRED TO.}

Cavers, F. (1914): Chondriosomes (Mitochondria) and their Significance. New Phyt., vol. xiii, 1914, pp. 96-106, 1 70-80.

(A complete bibliography prior to 1914 will be found here.)

Forenbacher, A. (1911): Die Chondriosomen als Chromatophorenbildner. Ber. der Deutsch. bot. Ges., vol. xxix, I9II, pp. 648-60.

1. Guilliermond, A. (1911): Sur les mitochondries des cellules végétales. Comptes Rendus, vol. cliii, I9I I, pp. I99-20I.

2. (1911): Sur la formation des chlorolencites aux dépens des mitochondries. Ibid., pp. 290-2.

3. (1911): Sur l'origine des leucoplastes et sur le processus cytologique de l'élaboration de l'amidon dans le tubercule de la pomme de terre. Ibid., pp. 1492-4.

4. - (1912): Sur les leucoplastes de Phagus grandifolius et leur identification avec les mitochondries. Ibid., vol. cliv, I9I2, pp. 286-8.

5. (1912): Sur les mitochondries des organs sexuels des végétaux. Ibid., pp. 888-9I.

6. (1912): Sur le mode de formation du pigment dans la racine de la carotte. Ibid., vol. clv, I9I 2 , pp. $4^{\mathrm{I} I-\mathrm{I}} 4$.

7. - (1913): Nouvelles observations sur le chondriosome des champignons. Ibid., vol. clvi, I9I3, pp. I78I-4.

8. $(1913)$ : Sur la formation de l'anthocyane au sein des mitochondries. Ibid., pp. $1924-6$.

9. (1913): Sur le rôle du chondriome dans l'élaboration des produits de réserve des champignons. Ibid., vol. clvii, 19I $3, \mathrm{pp} .63-5$.

10. (1913): Nouvelles recherches cytologiques sur la formation des pigments anthocyaniques. Ibid., pp. I000-2.

11. (1913): Sur la participation du chondriome des champignon dans l'élaboration des corpuscules métachromatiques. Anat. Anzeiger, vol. xliv, 1913, pp. 337-42. 
12. Guilliermond, A. (1914): Bemerkungen über die Mitochondrien der vegetativen Zellen und ihre Verwandlung in Plastiden. Eine Antwort auf einige Einwürfe. Ber. der Deutsch. bot. Ges., vol. xxxii, I9I4, pp. 282-30I.

13. $(1915)$ : Quelques observations cytologiques sur le mode de formation des pigments anthocyaniques dans les fleurs. Comptes Rendus, vol. clxi, I9I5, pp. 494-7.

14. (1915): Sur l'origine des pigments anthocyaniques. Ibid., pp. 567-70.

Janssens, F. A. (1913): Le chondriosome dans les champignons. La Cellule, vol. xxviii, I 913 , pp. 447 .

et Helsmortel, J. (1913): Le chondriosome dans les Saccharomycètes. Ibid., pp. $45^{\mathrm{I}-2 .}$ vesiculosa. Ibid., pp. 447-50.

1. Lewitsky, G. (1910): Ueber die Chondriosomen in pflanzlichen Zellen. Ber. d. Deutsch. bot. Ges., vol. xxviii, I910, pp. 538-46.

2. (1911): Vergleichende Untersuchungen über die Chondriosomen in lebenden und fixierten Pflanzenzellen. Ibid., vol. xxix, I9I I, pp. 68 5-96.

3. (1911): Die Chloroplastenanlagen in lebenden und fixierten Zellen von Elodea canadensis, Rich. Ibid., pp. 697-703.

1. Löwschin, A. M. (1914): Vergleichende experimental-cytologische Untersuchungen über Mitochondrien in Blättern der höheren Pflanzen. Ibid., vol. xxxii, 19I4, pp. 266-70.

2. (1914): Zur Frage über die Bildung des Anthocyans in Blättern der Rose. Ibid., pp. $3^{86-92 .}$

McAllister, F. (1914): The Pyrenoid of Anthoceros. Am. Jour. Bot., vol. i, I9I4, pp. 79-95.

Mirande, Marcel (1916): Observations sur le vivant de la formation cytologique de l'anthocyanine. Comptes Rendus, vol. clxiii, 1916, pp. 37I-86.

Rudolph, K. (1912): Chondriosomen und Chromatophoren. Ber. d. Deutsch. bot. Ges., vol. $\mathrm{xxx}, \mathrm{I912}, \mathrm{Pp} .605^{-27}$.

SAP̌̌Hin, A. A. (1913): Ein Beweis der Individualität der Plastiden. Ibid., vol. xxxi, I913, pp. $32 \mathrm{I}-4$.

Scherer, A. (1913): Die Chromatophoren und Chondriosomen von Anthoceros. Ibid., pp. $493-500$.

\section{EXPLANATION OF PLATE I.}

Illustrating Professor Mottier's paper on Chondriosomes and the Primordia of Chloroplasts and Leucoplasts.

All figures were drawn from sections with the aid of the camera lucida.

Fig. I. A cell from the root-cap of Pisum sativum, Marrow Fat variety. In the upper or distal half of the cell are several starch grains $(S t$.$) , in which the plastid appears as a dark, narrow crescent$ at one side. The dark granules and rods are chondriosomes. $\times 2,100$.

Fig. 2. A cell from the root-tip of Pisum, showing large rod-shaped primordia of lencoplasts and small, granular, and very delicate rod-shaped chondriosomes. The knob or head at one end of some of the primordia indicates the beginning of a starch inclusion. $\times 2,100$.

Fig. 3. An older cell from the central cylinder of the root. The transformation of primordia into leucoplasts is more evident. The starch inclusion in one end of the plastid is circular or oval, giving the leucoplast the form of a pear, club, or hand-mirror. The chondriosomes, as in the preceding figure appear as granules or delicate, slender rods. $\times 2,100$.

Fig. 4. Leucoplasts from older cells of the central cylinder of the root of Pisum. a, chondriosomes; $c, d$, and $e$, different forms of leucoplasts. At $c$ the oval starch inclusion lies near the centre of the plastid; in $b$ three inclusions are present; in $d$ the handle of the mirror-shaped plastid remained almost colourless, while the rest retained the stain. This form was rare. $\times 3,000$.

Fig. 5. Longitudinal vertical section through the apex of the thallus of Marchantia polymorpha, showing one apical cell with adjacent tissue and two young ventral scales. $a$ and $b$, mucilage hairs. The chondriosomes in $a$ are delicate rods of varying length; some of the rods seem to consist of 


\section{14 Mottier.-Chondriosomes and Primordia of Chloroplasts, Eंc.}

rows of rounded granules. In each cell the chloroplasts are the larger round or elliptical bodies, while the chondriosomes are very small granules and delicate, slender, bacteria-like rods. $\quad \times 1,250$.

Fig. 6. A cell a little farther behind the region of Fig. 5. n, nucleus; chloroplasts appear as ronnded or elliptical bodies; the smaller rods and granules are the chondriosomes. $\times \mathbf{I}, 500$.

Fig. 7. A cell older than that in Fig. 6, from beneath a dorsal air-chamber. The chloroplasts are mature, some showing division stages. The chondriosomes are relatively large. $\times$ I,500.

Fig. 8. A tangential view of an older cell, in which the chloroplasts are mainly confined to the thin peripheral layer of cytoplasm; they show a densely-staining shell with a colourless, lenticular inclusion. The chondriosomes are small, slender, homogeneous rods or granules, having, under the dry lens, the appearance of so many bacteria. Some of the rods appear to be composed of granules. $\times \mathbf{I}, 500$.

Fig. 9. A young rhizoid and a few cells of the lower epidermis. In the rhizoid are seen numerous rods and granules and the conspicuous nucleus. Many of the rods and granules are in process of division. The majority, if not all, of these are chondriosomes. In the epidermal cells, chondriosomes and chloroplasts are seen. $\times$ I,500.

Fig. Io. Pinus Banksiana. A cell from the cortex of the hypocotyl of a seedling $\mathrm{I} \mathrm{cm}$. in length. The chloroplasts appear round, oval, or elliptical. In some the inclusion is rounded; in others, lenticular. The chondriosomes are small rods and granules. $\times 1,500$.

Fig. II. Chloroplasts in different stages of maturity, from the same seedling as Fig. IO. $a$, from near base of cotyledon; the inclusions are either round or lenticular in form, two sometimes being present in a chloroplast; $b$ and $c$, mature chloroplasts from cortex of hypocotyl. If the chloroplasts are crowded, they become polygonal by mutual pressure, $c$. Some of these mature chloroplasts contain two or more bodies which behave like starch inclusions; others contain only one inclusion as in younger chloroplasts. Between the four chloroplasts at $b$ are shown five chondriosomes. At $c$ an adult chloroplast is in process of division. $\times 1,500$.

Fig. 12. An apical cell of the gametophyte of Anthoceros laevis, showing nucleus, chloroplast, and very delicate rod-shaped chondriosomes. $\times$ ז,250.

Fig. I3. An apical cell from the root of Adiantum pedatum. The relatively small leucoplasts are chiefly lenticular in form; the chondriosomes are rods and granules. $\times 1,500$.

Fig. 14. $a$, leucoplasts from the seventh layer of the root-cap of Adiantum; each contains two or more lenticular inclusions. $b$, a cell of the fifth layer of the root-cap; the leucoplasts are chiefly lenticular; the chondriosomes are small rods and granules. $\times 1,500$.

Fig. I 5. A cell from the central cylinder a short distance behind the apical cell in the root of Adiantum. The long conspicuous rods are primordia of leucoplasts; the smaller rods and granules are chondriosomes. $\times 1,500$.

Figs. 16 and $\mathrm{I} 7$. Parts of older elongating cells of the central cylinder of the root of Adiantum. In 16 , at the right, is a cluster of leucoplasts with starch inclusions. The primordia of leucoplasts, I6, I 7 , that did not develop into plastids are generally very long, thread-like, and flattened. These are undergoing disorganization. The chondriosomes are chiefly rounded granules and are present in countless numbers. $\times 1,500$. 


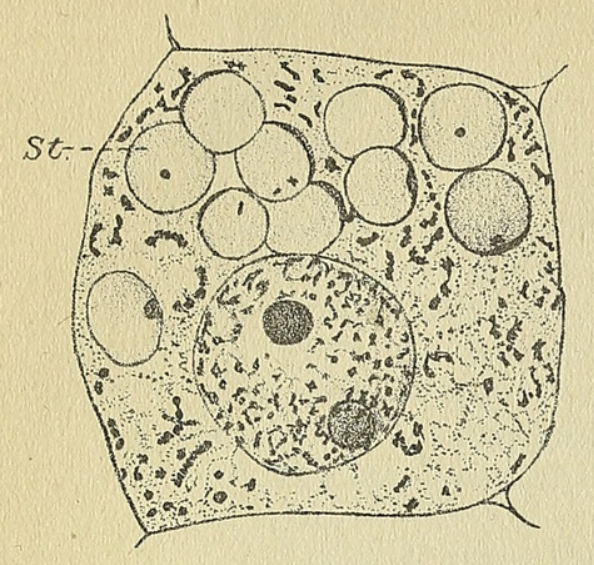

1.

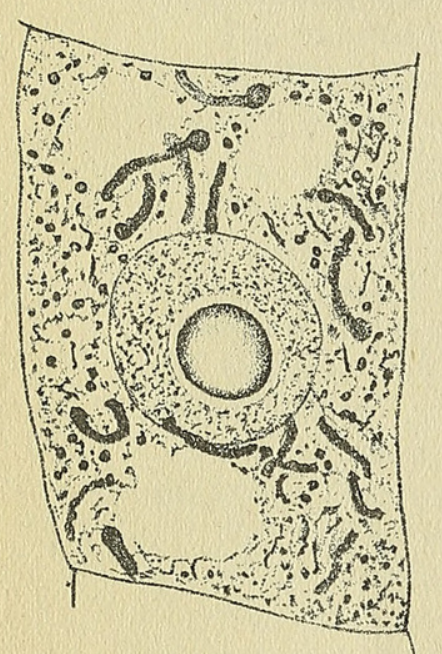

2.

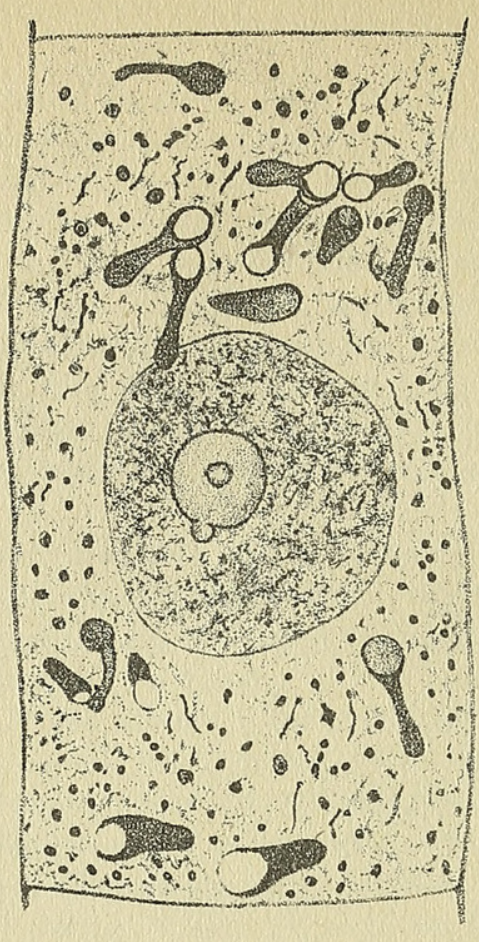

3
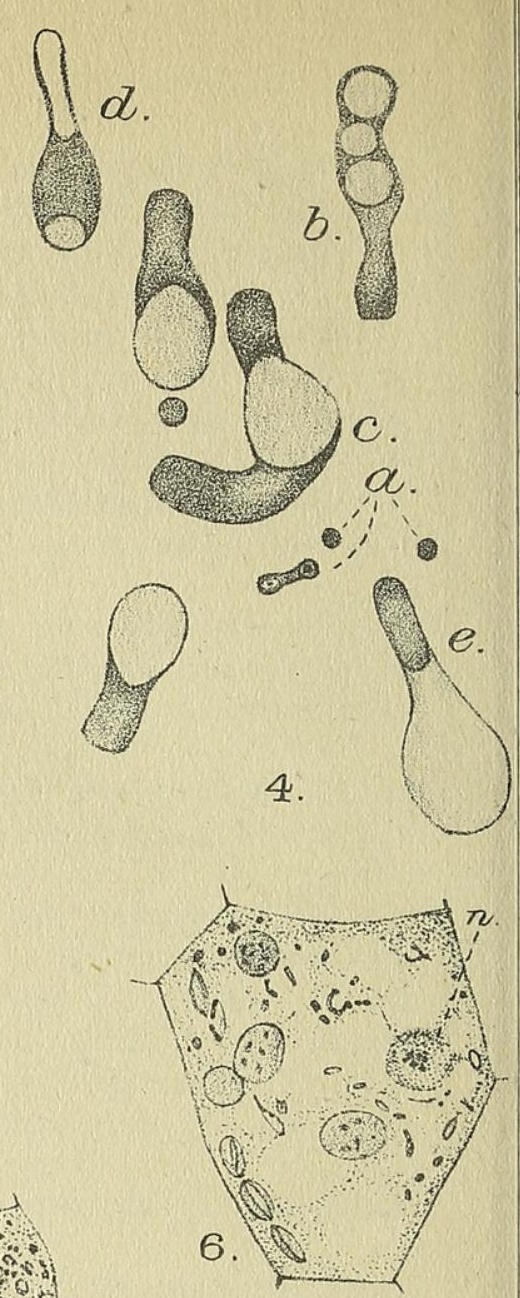

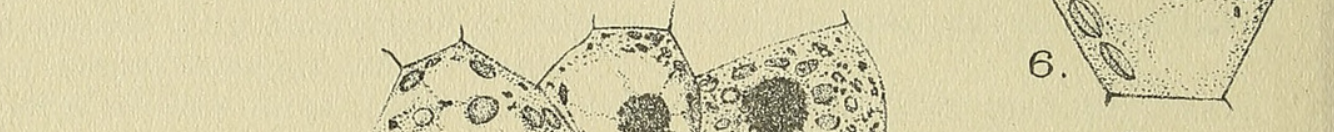

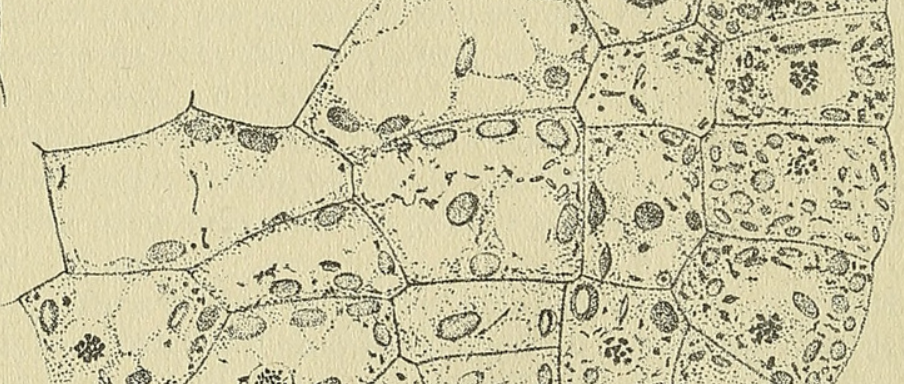

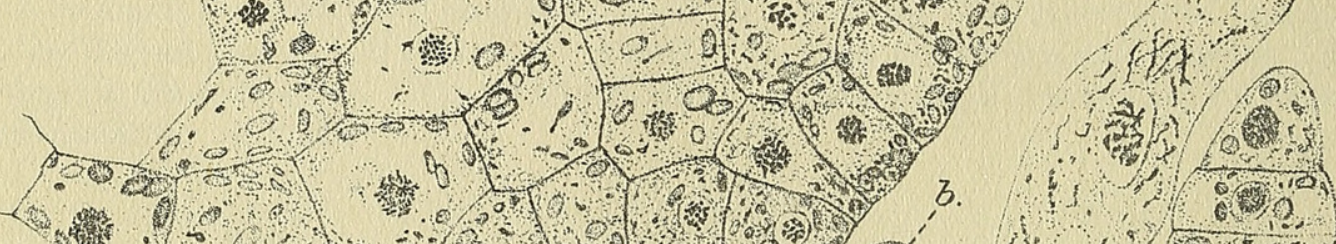
-4.

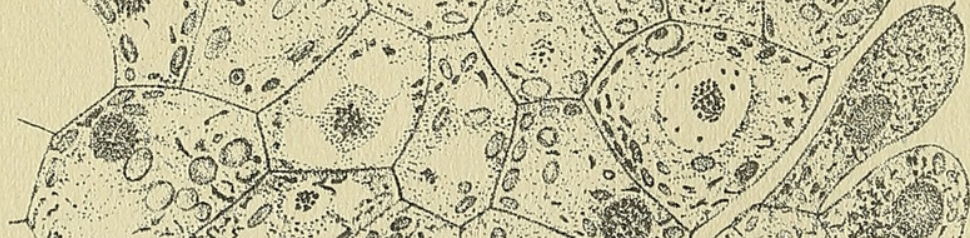

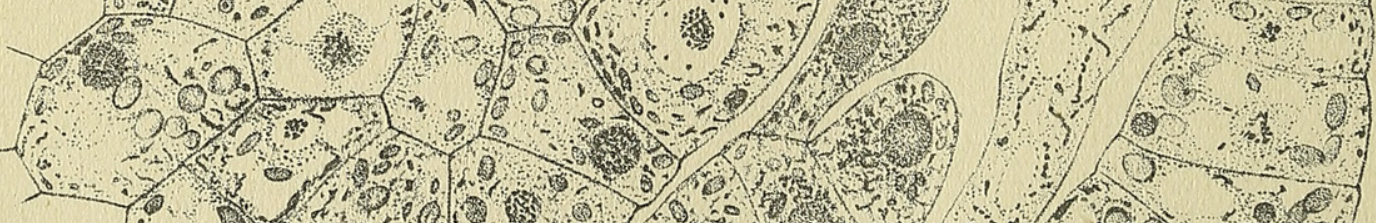

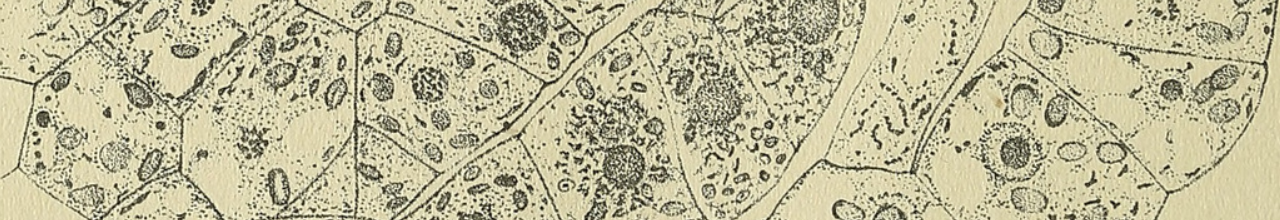

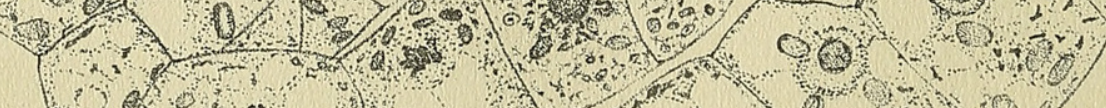

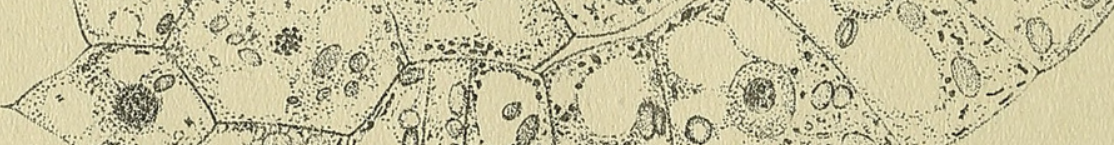
m.3.

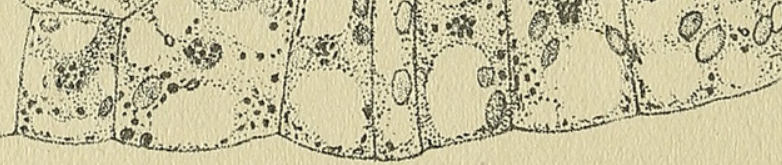




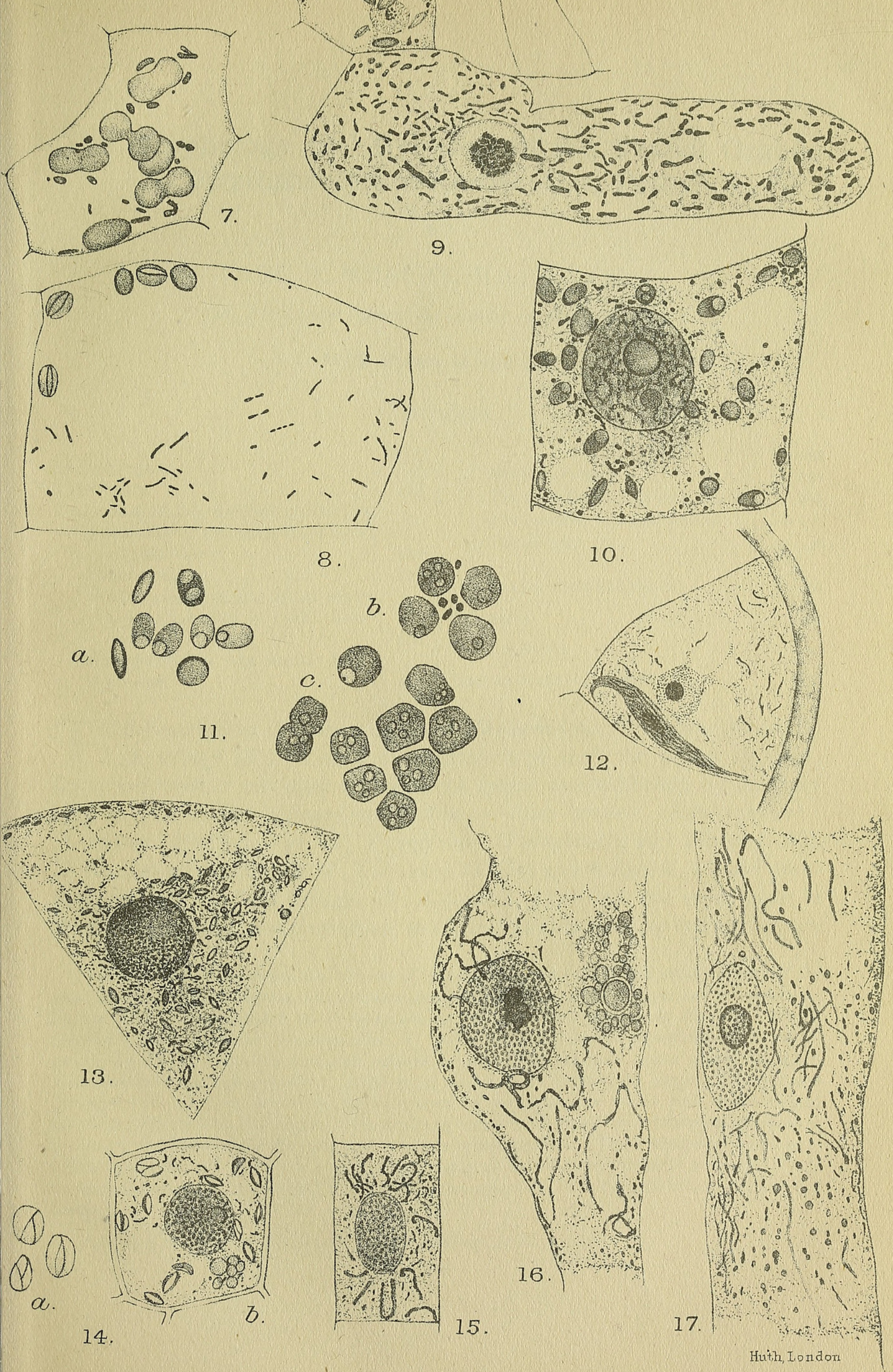




\section{$2 \mathrm{BHL}$ Biodiversity Heritage Library}

Mottier, David M . 1918. "Chondriosomes and the primordia of chloroplasts and leucoplasts." Annals of botany 32, 91-114.

https://doi.org/10.1093/oxfordjournals.aob.a089669.

View This Item Online: https://www.biodiversitylibrary.org/item/238284

DOI: https://doi.org/10.1093/oxfordjournals.aob.a089669

Permalink: https://www.biodiversitylibrary.org/partpdf/320209

\section{Holding Institution}

Smithsonian Libraries

\section{Sponsored by}

Biodiversity Heritage Library

\section{Copyright \& Reuse}

Copyright Status: Not in copyright. The BHL knows of no copyright restrictions on this item.

This document was created from content at the Biodiversity Heritage Library, the world's largest open access digital library for biodiversity literature and archives. Visit BHL at https://www.biodiversitylibrary.org. 